\title{
PROCESS WRITING APPROACH IN ENHANCING HIGH SCHOOL STUDENTS' ESL WRITING COMPETENCY
}

\author{
Justine P. Sarmiento ${ }^{1}$, ORCID ID: 0000-0002-8486-8805, \\ Ruth A. Ortega-Dela Cruz², ORCID ID: 0000-0003-1118-7117 \\ ${ }^{1}$ Department of Education, Division of Quezon, Nabangka National High School \\ Capuluan Central Guinayangan, Quezon, Philippines \\ ${ }^{2}$ Institute for Governance and Rural Development, College of Public Affairs and Development, University of the \\ Philippines Los Baños, Domingo M. Lantican Ave. College, Laguna, Philippines \\ ${ }^{*}$ Corresponding author: Ruth A. Ortega-Dela Cruz, raortegadelacruz@up.edu.ph
}

Received: 10. 01. 2021

Accepted: 11. 17. 2021

\begin{abstract}
This study was conducted to determine the impact of using process approach in writing narrative composition for Senior High School students who were taking Reading and Writing subject. It focused on determining students' progress in writing narrative composition in terms of organization, coherence, appropriate language use, and mechanics. The study used quasi-experimental one-group pretest-posttest design wherein the respondents, who were chosen through total population sampling, underwent pre-test in which they were tasked to write narrative composition using traditional approach. Process writing approach was implemented with the use of activity manual as teaching- learning guide wherein the final output was evaluated as post-test of the study. Based on the findings, Senior High School students were not competent in writing narrative composition especially in terms of coherence, appropriate language use and mechanics using traditional approach. But with the use of process writing approach, the students were assessed to become proficient in four writing competencies. Thus, the study recommended the use of process writing approach as it was found effective in enhancing students' competency in writing narrative composition.
\end{abstract}

Keywords: English, narrative composition, process writing approach, writing competency.

Rezumat. Acest studiu a fost realizat pentru a determina impactul utilizării abordării de proces în scrierea compoziției narative pentru elevii de liceu care urmau disciplinele Citire și Scriere. S-a concentrat pe determinarea progresului elevilor în scrierea compoziției narative în ceea ce privește organizarea, coerența, utilizarea adecvată a limbajului și mecanica. Studiul a folosit un design cvasi-experimental, pre-test - post-test, într-un singur grup, în care respondenții, care au fost aleși prin eșantionarea populației totale, au fost supuși unui pre-test în care au fost însărcinați să scrie o compoziție narativă folosind abordarea tradițională. Abordarea procesului de scriere a fost implementată cu utilizarea manualului de activități ca ghid de predare-învățare, în care rezultatul final a fost evaluat ca post-test al studiului. Pe baza constatărilor, elevii de liceu nu erau competenți în scrierea 
compoziției narative, în special în ceea ce privește coerența, utilizarea adecvată a limbajului și mecanica, folosind abordarea tradițională. Dar, prin utilizarea abordării procesului de scriere, elevii au fost evaluați să devină competenți în patru modalități de scriere. Astfel, studiul a recomandat utilizarea abordării procesului de scriere, deoarece a fost găsit eficient în îmbunătățirea competenței elevilor în scrierea compoziției narative.

Cuvinte cheie: engleză, compoziție narativă, abordare proces de scriere, competență de scriere.

\section{Introduction}

Across generations, numerous pedagogical strategies have evolved especially in the field of language teaching. Despite methodological innovations, writing remains to be a complicated area for English as a Second Language (ESL) learners. [1] posited that students perceive writing more difficult than other macro-skills for it requires productivity. Through extensive research, most ESL teachers have developed state-of-the-art approaches to aid student difficulties in writing. One of which is the process approach which several researchers accentuated as the scheme for effective writing for it pays attention to the development of writing practices. This approach has become effective to writing classrooms because it provides students with flexibility, practicality, and applicability [2].

Process writing approach is a systematic approach to writing where language teachers concentrate on evaluating students' writing performance during the stages of developing their output rather on the product itself. [3] explicated that writing process comprises stages such as (1) prewriting, (2) drafting, (3) revising, (4) editing and proofreading, and lastly (5) publishing and presenting. Various studies substantiate that using the stages of the writing process help students convey their thoughts in compositions for they are provided with ample time and opportunity to accomplish well- written outputs with the assistance of the teacher as facilitator of the learning methodology.

Moreover, being learner-centred is one of the best features of this writing approach. It is where teachers play the role of being facilitators. [4] explained that writing is a skill that is being learned and not being taught that is why teachers' duty is to facilitate the writing stages. Each step has corresponding techniques that are being recommended by the teacher to the students to have a well-thought-out output. Consequently, learners' writing potentials will be brought out.

In the emergence of $\mathrm{K}$ to 12 programs in the Philippines, the Department of Education primed writing courses in Senior High School level to develop students' advanced writing skills. Additionally, students are expected to perform varied levels of writing competencies in which they are tasked to focus on the effective utilization of language and articulation of ideas and experiences in their compositions.

Relevantly, [5] stated that with an increase in attention to the practical needs of students of present generation, functional and interactive approach of writing should be applied and developed. Therefore, teachers should adapt applicable approaches, like process writing. This approach aims to develop students' writing competencies particularly organization, coherence, appropriate language use, and mechanics which are specified in the Department of Education's [6] Reading and Writing curriculum guide as properties of wellwritten text.

However, based on students' background in writing compositions, most of their writing teachers used traditional strategy of instruction wherein students are tasked to accomplish texts focusing on the finished product and not on the process of developing their output. This 
approach on reproducing writing models disregards teacher's input and discourages students' creativity [7].

Reading and Writing is one of the core subjects in senior high school that clearly aims to develop learner's writing skills. The students are expected to produce compositions that should follow the properties of well-written text. These are organization, coherence, appropriate language use, and mechanics. However, students encounter problems in working out their writing tasks due to their weak foundational skills and interest in writing.

In usual language classes in the country, students are just engaged in product- based learning especially in writing composition and other written tasks. They encounter jeopardy in writing in the absence of the functional and organized writing practices and activities for teachers view product approach as practical teaching-learning strategy. From various research, teachers most often choose an approach that can ease their task effectively in teaching writing and introducing text-types to finish the course objectives on time. As a result, the students become dependent writers especially in familiarizing model essays and accomplishing writing activities [8]. Aside from that, some writing classes are still confined with traditional practices. Teachers' evaluation of students' written products only focuses on the formal features in which accuracy are all important where prewriting and developing the text based on the errors are being overlooked. [9] emphasized that these classroom conditions result to unsuccessful acts of writing and consequently, unsuccessful text.

Most ESL classrooms utilize traditional approach in their writing classes wherein they are expected to build up highly structured texts without activities that will help them to choose topic, generate ideas, gather details, outline, revise, edit, and finalize their outputs. These stumbling blocks may cause vague purpose in writing and obscure presentation of ideas based on particular issue of discourse. This is supported by [10] who revealed that mechanics, language use, and organization are the prime problems of Filipino ESL students in writing especially in terms of word choice, grammar, and punctuation.

This issue is particularly true to the case of Senior High School students in a Private School in Majayjay, Laguna, Philippines. They are among those who experience the difficulties in writing composition. To conform towards the challenges and standards of present educational system, process writing approach is assumed to be effective and profound approach in developing students' writing skills. It is where the students convey their ideas in written form through complex, indeed systematic process.

For the attainment of expected outcomes of the Reading and Writing subject, the study was conducted in which the results were anticipated to become basis in developing students' writing skills. Generally, the study sought answer to the question: Did the use of process approach have an impact on writing narrative composition of Senior High School students who took Reading and Writing for the school year 2017-2018?

The study specifically: (i) determined the students' level of writing competency in writing narrative composition in terms of organization, coherence, appropriate language use, and mechanics before and after the implementation of process writing approach; (ii) analysed the pre-test and post-test scores in writing narrative composition in terms of organization, coherence, appropriate language use, and mechanics; and (iii) evaluated the effectiveness of the learning activity manual in the following stages of process writing approach: a) prewriting, b) drafting, c) revising, d) editing and proofreading, and e) publishing and presenting. 


\section{Process Writing Approach}

As a thought-provoking and methodical approach to writing, process writing approach is viewed by several research as a valuable tool to the learners for they are being provided with opportunities that could develop writing practices and skills. They are being engaged in accomplishing writing tasks offered by each stage to come up with well- written composition.

According to [9] the process writing approach treats writing not as a completed product but as a process. [11] stated that writing as a process allows time for the prewriting and drafting and encourages students to revise and edit their work. As the teacher demonstrates the steps one by one, students will be able to have an in-depth understanding of the writing process.

Likewise, Tribble [5] defined the process approach as "an approach to the teaching of writing which stresses the activity of the individual writer, and which pays attention to the development of good writing practices rather than the imitation models". By breaking down the task into its constituent parts, writing is greatly less intimidating and more practicable for the students. The stages generally involve different forms of brainstorming, selecting, and ordering ideas, planning, drafting, redrafting, and revising and editing. This not only provides the student writer and the teacher with a practical and manageable framework within which to work through the writing process, but also allows for great flexibility, depending on each individual task and the personality and preferences of each individual writer.

Process writing approach assists ESL students, whatever their ability level, improve their writing in different genre [12]. In addition, it values talents, capabilities, and growth of individual writers. [13] explained that process writing approach helps to bring about positive changes in the most students' attitudes towards writing and improvements in writing habits. Furthermore, [14] pointed out that an important element of process writing approach is the meaningfulness and functionality it brings to the learners, who make a personal connection to the topic and come to understand the processes they follow when writing about it.

Bonesall [15] enumerated and explained distinct stages of composition: (1) Prewriting where the writer gathers information and plays with ideas. [16] shows that students who experienced array of prewriting activities have greater writing achievement. (2) Drafting where the writer develops his/her topic on paper that focuses on content rather than mechanics; (3) revising where the writer changes what is necessary in terms of organization, coherence, and language; (4) editing where the writer polishes the draft and gives attention to mechanics; and (5) publication where the writer delivers the writing to its target audience. [15] underscored that to have a well-thought-out composition, students should pay attention to the process and the properties of well-written text at the same time.

[17] posited that writing in process approaches is seen as predominantly to do with linguistic skills, such as planning and drafting. There are different views on the stages that writers go through in producing a piece of writing, but a typical model identifies four stages: prewriting, composing, revising, and editing. This is a cyclical process in which writers may return to prewriting activities. A typical prewriting activity in the process approach would be for learners to brainstorm on the topic. At the drafting stage, they would select and structure the result of the brainstorming session. After discussion, learners might revise the first draft individually or by group. Finally, the learners would edit or proofread the text. The whole process is facilitated by the teacher.

Specifying the advantages offered by process writing approach, [18] enumerated the following: (1) It focuses on the process, not on the final product; (2) It finds a real audience; 
(3) It offers a variety of techniques; (4) The teacher plays the role of guide, facilitator, and reader; (5) Student's role is one of sharing and collaborating; (6) Grammar is a tool - a means, not an end; meaning is essential, not form; (7) It is a creative process; and (8) Evaluation and feedback are given permanently, not only at the end.

There are more potential advantages of using process writing approach as stated by [19]. First, students are encouraged to plan, draft, and revise. Second, instruction in writing through mini-lessons, conferences, and teachable moments result in improved quality of writing. These teaching tools also provide mechanisms for addressing the instructional needs of the individual students. Third, motivation for writing should be enhanced as collaboration, personal responsibility, personal attention, and the positive learning environment are stressed.

\section{Materials and Methods \\ Research Design}

The study used quasi-experimental one-group pre-test-post-test design to determine the impact of process writing approach on a given sample of students. A single group of Senior High School students was pretested, and they were tasked to write narrative composition using traditional approach (product-based). Given some treatment or intervention such as the use of process writing approach, they were post-tested. If the pretest and posttest scores differed significantly, then the difference may be attributed to that treatment or intervention which is the process writing approach.

\section{Subjects of the Study}

The subjects of the study were purposively chosen 53 Grade 11 students from a Private School in Majayjay, Laguna, Philippines. They were from two heterogeneous classes who took Reading and Writing subject. Through total population sampling, 26 students from Grade 11St. Augustine and 27 from Grade 11-St. Basil experienced process writing approach in their subject Reading and Writing.

\section{Instrumentation}

Parallel pre-test and post-test rubrics were used to identify the students' scores in their narrative written tasks. Based in Reading and Writing curriculum guide provided by DepEd [6], this tool contains components that evaluate student's written outputs in both tests such as organization, coherence, appropriate language use, and mechanics. The standards used in measuring the students' writing performance were Poor, Developing, Proficient, and Advanced. The pre-test tasked the students to write a short story using the traditional approach while post-test engaged the students to write short story using process writing approach. Both outputs were evaluated through the rubrics that were adapted from [20] rubrics in scoring students' composition. The rubrics were validated by high school and college language teachers and were found appropriate for the scoring of the students' composition.

Another instrument used was learning activity manual that was planned, designed, and implemented. This served as teacher's and learner's guide in facilitating the activity and writing the short story respectively. It underwent validation to see its applicability in the language class.

Lastly, the survey-type questionnaire was used as tool in revealing students' perception on the effectiveness of the learning activity manual in the following stages of 
Process Writing Approach: prewriting, drafting, revising, editing, and proofreading, and publishing and presenting. The checklist questionnaire was constructed based on extensive literature taken from printed and online sources.

Experts' assistance was sought for validation of all the instruments used. In particular, the instruments undergone face validity where they were reviewed by two different parties. The first group was consisted of three English language education specialists. They evaluated the questions/statements and made sure that each question/statement successfully captured the research topic and problem. The second review was done by a statistician who ensured that the scoring was accurate and the survey and did not contain common errors such as leading, confusing, or double-barreled questions/statements. The researcher also run a pilot test of the survey and reviewed the internal consistency of questions by conducting the test of reliability with test-retest to a group of 20 Grade 11 students from another private school. The administration of retest was three weeks after the first test. Likewise, the Cronbach-Alpha method was applied, and the result got a total test and retest scores $(0.76$ and 0.78$)$ with a reliability factor of 'acceptable'.

The following procedures on administering the instruments were discussed in detail:

Interview. Before the conduct of the study, the researcher asked the classes about their background in writing composition, the teaching approach used by their previous language teachers as well as their strengths and weaknesses in writing. One hundred per cent of the students utilized traditional approach in writing during their junior high school and did not experience process writing approach.

Pretest. The researcher conducted a pretest wherein students were tasked to write a narrative composition specifically short story using the traditional approach of writing that they all experienced in their previous years of writing composition. The outputs were evaluated by two English teachers using the adapted rubrics.

Implementation of Process Writing Approach Activity Manual. The manual served as students' guide in writing narrative composition. It also introduced them how process writing approach works so their perception to the approach would be revealed and their interests would be determined.

Design. Before the implementation of the learning activity manual, design and development of the instructional material were done to make the teaching-learning process well-planned and organized. In design stage, the researcher prepared a lesson plan regarding writing narrative text specifically making a short story. The learning plan is patterned on the $\mathrm{K}$ to12 Curriculum Guide for Grade 11 Reading and Writing subject with learning competency - distinguish among patterns of development in writing across disciplines: narration, description, definition, classification, comparison and contrast, cause and effect, problem solution and persuasion.

Development. In terms of the development and construction of the process writing approach activity manual, the researcher first identified the objectives which were parallel in the learning plan. Research was done for the content, strategies, flow of the lesson, and rubrics. Then, the researcher designed and developed the activity manual containing the following parts of the material: cover page, preface, attribution, table of contents, lesson proper, stages of writing, written output rubrics, and appendices. The structure of the material was patterned from [3] process writing book entitled Prentice Hall Writing and Grammar.

Implementation. The researcher implemented the process writing approach activity manual to Grade 11 Reading and Writing students for three consecutive days. All the activities 
in the manual were facilitated by the researcher and were accomplished based on the target schedule.

Posttest. The output that the students produced in the process writing activities served as posttest. The written output was evaluated by same two English teachers through the same rubrics used in the pretest. The results of pretest and posttest were subjected to appropriate statistical treatment for interpretation.

Administration of Survey-type Questionnaire. In another session, the researcher administered the questionnaire. One hundred per cent retrieval of questionnaire was ensured. Afterwards, the transcription of the surveys and analysis of results of the study were done using quantitative method. Data were tallied, tabulated, analyzed, and interpreted using appropriate statistical tools.

\section{Data Analysis}

Descriptive statistics such as mean, percentage and standard deviation were used to analyse the data obtained from the questionnaires. The mean of the students' scores were used in presenting and analysing the difference between the pre-test and post-test scores in writing narrative composition. The standard scores in the rubrics were used for the analysis which were categorised as Poor, Developing, Proficient, and Advanced. Concerning the perception of students on the effectiveness of the learning activity manual used in implementing the process writing approach, the five-point Likert scale ranging from needs improvement (1) to superior (5) was used.

\section{Results and Discussions}

\section{Students' Level of Writing Competency in Writing Narrative Composition}

Finding shows that the mean of the pre-test total scores of Grade 11 students in writing narrative composition before using process writing approach were generally proficient (Table 1). In particular, 36 per cent $(n=53)$ of the students were in proficient level, 30 per cent $(n=53)$ were in developing level, 19 per cent $(n=53)$ were in the poor level, and 15 per cent $(n=53)$ are in advanced level. The students were proficient in terms of organization with mean of 10.9. Further, the students' levels of competency regarding coherence, appropriate language use, and mechanics were developing with weighted means of $10.5,9.77$, and 9.98 respectively. The results imply that most of the students have struggle in writing in all aspects especially appropriate language use and mechanics which gained the lowest means.

Table 1

Students' level of writing competency in writing narrative composition

\begin{tabular}{lccc}
\hline & $\overline{\mathbf{x}}$ & $\begin{array}{c}\text { General Assessment } \\
\text { Verbal Interpretation }\end{array}$ & SD \\
\hline Organization & 10.9 & Proficient & 3.65 \\
Coherence & 10.5 & Developing & 3.70 \\
Appropriate Language Use & 9.77 & Developing & 3.83 \\
Mechanics & 9.98 & Developing & 3.67 \\
Overall Weighted Mean & 41.2 & Proficient & 14.46 \\
\hline
\end{tabular}

Range: General Assessment (1-5 Poor; 6-10 Developing; 11-15 Proficient; 16-20 Advanced); Total Scores Mean (1-20 Poor; 21-40 Developing; 41-60 Proficient; 61-80 Advanced). 
This affirms the study of [21] who found language use and vocabulary aspects as the most difficult among the students in writing English. Next to these were the organization and mechanics aspects.

From the researchers' initial interview with the respondents, most of the students mentioned that included among the problems they encounter in writing compositions were sentence construction, grammar, and punctuation. This supports the studies of [22] and [10] who found out that students struggle mostly in vocabulary and mechanics. Students find it difficult to express their ideas and thought to the paragraph writing and so they make many grammatical mistakes in their writing [23]. In fact, vocabulary has been found to have an important role in the quality of written outputs [24 - 25]

\section{Students' Progress in Writing Narrative Composition}

Table 2 shows that the overall level of students' writing competency after using process writing approach was proficient with total scores mean of 55.85. Specifically, the students' writing performance with the use of process writing approach was proficient in all four criteria which are organization, coherence, appropriate language use, and mechanics with the mean of $14.26,14.15,13.53$, and 13.91 . This study coincides with the findings of [18] which explains that the implementation of process writing approach activities is a 'communicative experience' that encourages learners to practice and develop their writing skill in a controlled situation which in turn provides good results. Also, [26] concluded that process writing approach is an effective strategy to improve writing for it uses several writing instructional activities that stresses extended writing opportunities, writing for authentic audiences, and personalized and interactive teaching-learning process.

Just like in pre-test, appropriate language use still has the lowest means which implies that there were still students who struggle in terms of grammar and vocabulary. This supports the study of [22] who found developing ideas and grammar as the main problem for English Education Department students. This was followed by use of vocabulary and language expressions. Similarly, the Grade 11 students had difficulties with producing grammatically correct sentences and of using appropriate words in their academic writing.

Table 2

Students' Progress in Writing Narrative Composition

\begin{tabular}{llll}
\hline & $\overline{\mathbf{x}}$ & $\begin{array}{l}\text { General Assessment } \\
\text { Verbal Interpretation }\end{array}$ & SD \\
\hline Organization & 14.26 & Proficient & 2.47 \\
Coherence & 14.15 & Proficient & 2.36 \\
Appropriate Language Use & 13.53 & Proficient & 2.82 \\
Mechanics & 13.91 & Proficient & 2.57 \\
Overall Weighted Mean & 55.85 & Proficient & 9.92 \\
\hline
\end{tabular}

Range: General Assessment (1-5 Poor; 6-10 Developing; 11-15 Proficient; 16-20 Advanced); Total Scores Mean (1-20 Poor; 21-40 Developing; 41-60 Proficient; 61-80 Advanced).

The students' progress in writing narrative composition is evident because 57 per cent $(n=53)$ of the students were in proficient level, 32 per cent $(n=53)$ were in advanced level, 11 per cent $(n=53)$ were in developing level, and none of the students is in poor level.

The findings are in congruence with the study of [2] which stated that students can manage the organization of their composition for they were provided with activities wherein 
they have the chance to think as they write. However, the study also underscored that the concern of students towards process writing approach is that grammar and structure is not the prime focus of the writing process. Further, based on the observation of the researcher during the implementation of the manual, the students easily organized their thoughts in writing and presented clearly their ideas because of prewriting activities. Though, there were few students who asked for assistance for them to have grammatically- correct and wellstructured sentences. In all, using process writing approach is a great help for the students in improving their writing skills. [13] explained that process writing approach helps to bring about positive changes in the most students' attitudes towards writing and improvements in writing habits.

\section{Analysis of Pre-test and Post-test Scores in Writing Narrative Composition}

Evident in the Figure 1 that the post-test scores in organization, coherence, appropriate language use, and mechanics were higher than pre-test scores. The results imply that using process writing approach is effective and can contribute to the development of students' level of writing competency.

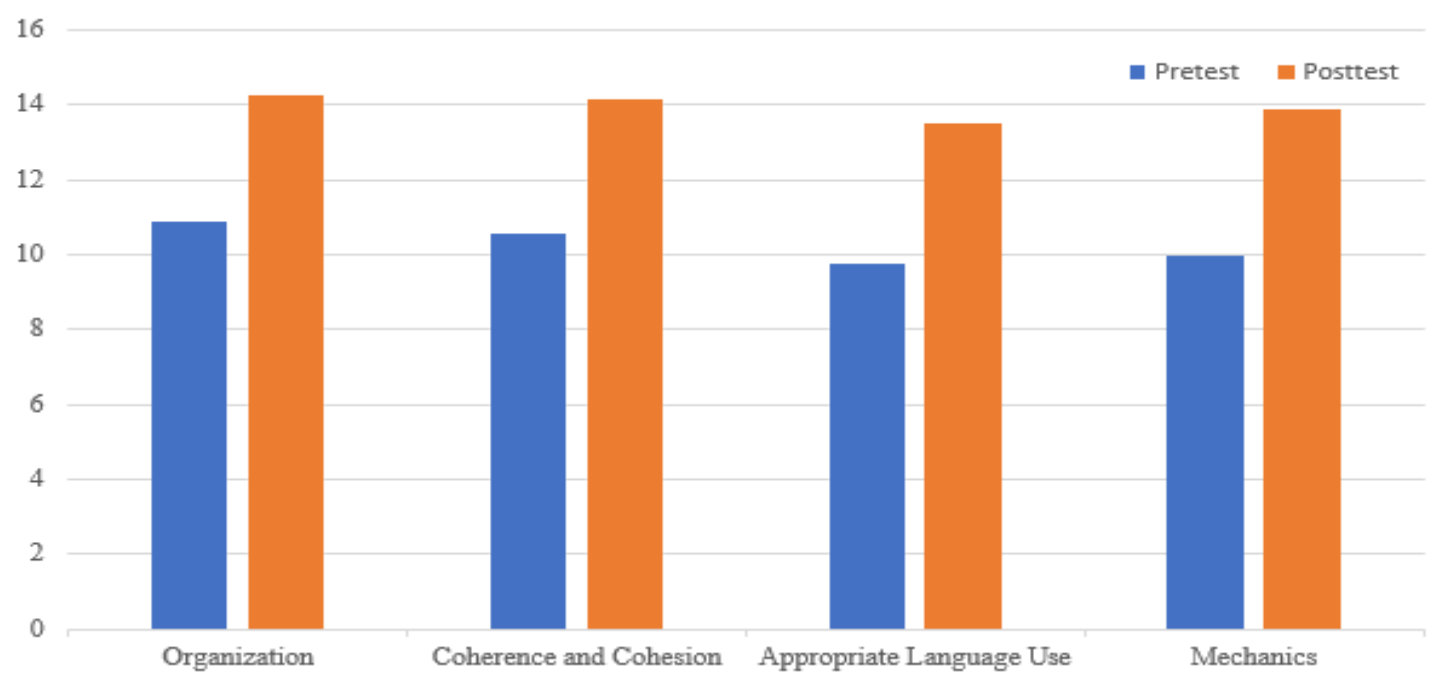

Figure 1. Means of Pretest and Posttest Scores.

The students were proficient in terms of organization and developing level in terms of coherence, appropriate language use, and mechanics and after using process writing approach, they became in proficient level along with organization. Indeed, process writing approach had a significant effect on students' writing success [9].

The researcher observed during the implementation that the students find writing less problematic with the use of process writing approach for they applied strategies in planning and developing their compositions. Most of the respondents commented that process writing approach helps them to write a story that is clear and understandable for the target readers.

The result of the study accords with the study of [27] which posited that process writing approach can minimize writing difficulty for it serves as a tool in structuring students' composition with interesting and well-framed content. In addition, the teacher-student interaction throughout the writing process provides direction for them to achieve the lesson objectives. This also supports the conclusions drawn by [9], [28 - 32] who explained that process writing approach affected students' writing success in a positive and statistically significant way. Collaboration with their classmates and their teacher, texts contain leads to fewer errors because they play vital roles in improving their written output. 


\section{Effectiveness of Learning Activity Manual}

Table 3 shows that the overall level of effectiveness of the learning activity manual as assessed by the students is superior $(\bar{x}=4.60)$. Specifically, the results show that the effectiveness of the material's activities and strategies under prewriting, drafting, editing, and proofreading, and publishing and presenting were superior with mean of 4.64, 4.57, 4.61, and 4.73. While in terms of revising, the students' assessment was above average $(\bar{x}=4.46)$.

The findings imply that the activities and strategies used in the manual were effective enough to achieve the objectives of the lesson and guided students meaningfully in accomplishing their narrative composition. Further, the designed learning material contributed greatly to the progress of students' writing competency in which each stage of process writing approach became beneficial for them in accomplishing their composition. This is true given that the process writing approach treats writing not as a completed product but as a process [9]. It focuses on the student in writing compositions, and the teacher only acts as a guide.

Table 3

Level of Effectiveness of Learning Activity Manual

\begin{tabular}{llll}
\hline & $\overline{\mathbf{x}}$ & $\begin{array}{l}\text { General Assessment } \\
\text { Verbal Interpretation }\end{array}$ & SD \\
\hline Prewriting & 4.64 & $\mathrm{~S}$ & 0.78 \\
Drafting & 4.57 & $\mathrm{~S}$ & 0.07 \\
Revising & 4.46 & $\mathrm{AA}$ & 0.13 \\
Editing and Proofreading & 4.61 & $\mathrm{~S}$ & 0.19 \\
Publishing and Presenting & 4.73 & $\mathrm{~S}$ & 0.07 \\
Overall Assessment & 4.60 & Superior & 0.10 \\
\hline
\end{tabular}

Range: 4.50 - 5.00 Superior (S); 3.50 - 4.49 Above Average (AA); 2.50 - 3.49 Average (A); 1.50 - 2.49 Below Average (BA); $1.00-1.49$ Needs Improvement (NI).

The findings of the study support [33] who concluded that through process approach, the students were able to make use of the pre- writing stage to explore, link and generate new ideas. Also, different stages of the writing process (pre-writing, drafting, revising, editing, and publishing) provided the students with an opportunity to improve their writing in terms of organization of ideas and mechanics of writing.

\section{Conclusions}

The findings reveal that using traditional approach in writing, the level of writing competency in writing narrative composition is proficient in terms of organization and developing in coherence, appropriate language use, and mechanics. Their overall level of writing competency is proficient but near to developing level because majority of the students find difficulty in grammar, vocabulary, and punctuation.

However, after the implementation of the process writing approach activity manual, the results show that the level of students' writing competency became proficient. Thus, the study recommended the use of process writing approach in writing narrative composition for it is found is effective in helping students to enhance their competency in writing narrative composition. It is also recommended for English teachers to: (i) make use of process writing approach in teaching writing of various text types for them to help students effectively in 
developing written outputs; (ii) utilize more relevant, interesting, and useful materials to enhance students' writing competency with regard to their needs and interests; (iii) improve the activity manual especially activities under revising stage to have more effective guide in writing narrative text; (iv) identify the strengths and weaknesses in writing composition of every group of students for them to become guided in choosing teaching-learning materials; (v) monitor regularly the performance and progress of the students to see if the strategies and materials are effective tools in teaching; (vi) integrate other interactive and interesting writing approaches that will make students motivated in developing their writing skills; and (vii) evaluate and revise the learning material based from the needs of the target students.

The support of the school administration in developing pedagogical methodologies provides strong motivation for the students and teachers to attain excellence in writing. For them to make it happen, they are suggested to: (i) strengthen programs especially language courses or subjects that focus on writing skills; (ii) organize academic and co-curricular activities that will enhance students' language competencies; and (iii) produce the needed learning material made available in good quality and sufficient quantity. By exposing their teachers to various training and seminars, they will be equipped with the knowledge and skills on innovative pedagogical techniques needed to enhance the student's writing competency.

\section{References}

1. Berman R., \& Cheng L. (2001). English academic language skills: Perceived difficulties by undergraduate and graduate students, and their academic achievement. Canadian journal of applied linguistics, 25-40. https://journals.lib.unb.ca/index.php/CJAL/article/view/19830/21602

2. Onozawa C. (2010). A study of the process writing approach. Research Note, 10, 153-163. https://gair.media.gunma-u.ac.jp/dspace/bitstream/10087/7218/1/2010-onozawa2.pdf

3. Carroll J. A., Wilson E. E., \& Forlini G. (2004). Prentice Hall Writing and Grammar: Communication in Action. Copper Level. Recording for the Blind \& Dyslexic.

4. Rusinovci X. (2015). Teaching writing through process-genre based approach. US-China Education Review, 5(10), 699-705. http://www.davidpublisher.org/Public/uploads/Contribute/564943e786db7.pdf

5. Holmes N. (2006). The use of a process-oriented approach to facilitate the planning and production stages of writing for adult students of English as a foreign or second language. Retrieved December, 9, 2012. https://www.developingteachers.com/articles_tchtraining/processw1_nicola.htm

6. Department of Education (DepEd) (2013). K to 12 Senior High School Core Curriculum - Reading and Writing Skills December 2013. Retrieved 21 July 2020 from https://www.deped.gov.ph/wpcontent/uploads/2019/01/SHS-Core_Reading-and-Writing-CG.pdf.

7. Huy N. T. (2015). Problems affecting learning writing skill of grade 11 at Thong Linh high school. Asian Journal of Educational Research, 3(2).

8. Palpanadan S. T. A. P., Salam A. R., \& Ismail F. (2014). Comparative analysis of process versus product approach of teaching writing in Malaysian schools: Review of literature. Middle-East Journal of Scientific Research, 22(6), 789-795. https://www.idosi.org/mejsr/mejsr22(6)14/1.pdf

9. Bayat N. (2014). The Effect of the Process Writing Approach on Writing Success and Anxiety. Educational Sciences: Theory and Practice, 14(3), 1133-1141. https://files.eric.ed.gov/fulltext/E1034097.pdf

10. Gustilo L., \& Magno C. (2012). Learners' errors and their evaluation: The case of Filipino ESL writers. Philippine ESL Journal, 8(9), 96-113.

https://www.academia.edu/16194697/Learners_errors_and_their_evaluation_The_case_of_Filipino_ESL_writ ers_Philippine_ESL_Journal_8_96_113

11.Spandel V. (2008). Creating Young Writer: Using the Six Traits to Enrich Writing Process in Primary Classrooms: USA: Pearson Education, Inc.

12.Jarvis D. J. (2002). The Process Writing Method. The Internet TESL Journal, Vol. VIII, No. 7, July 2002 http://iteslj.org/ http://iteslj.org/Techniques/Jarvis-Writing.html 
13. Ho B. (2006). Effectiveness of using the process approach to teach writing in six Hong Kong primary classrooms. Perspectives: Working papers in English and communication, 17(1), 1-52. http://citeseerx.ist.psu.edu/viewdoc/download?doi=10.1.1.456.5797 \& rep=rep1\&type=pdf

14. Yan G. (2005). A process genre model for teaching writing. English Teaching Forum, 43(3), 18-26.

15. Altovar I. C. (2012). Performance in English Composition Writing of High School Students in Binagbag National High School: Basis for the development of Enhancement Program Composition Writing. Lucena City, Philippines: Sacred Heart College Graduate School

16. Mogahed M. M. (2013). Planning out pre-writing activities. International Journal of English and Literature, 4(3), 60-68. https://academicjournals.org/journal/JEL/article-full-text-pdf/D68940D3788

17. Badger R., \& White G. (2000). A process genre approach to teaching writing. ELT journal, 54(2), 153-160. https://doi.org/10.1093/elt/54.2.153

18. Ariza Martinez A. V. (2005). The process-writing approach: An alternative to guide the students compositions. Profile Issues in Teachers Professional Development, (6), 37-46. http://www.scielo.org.co/scielo.php?script=sci_arttext\&pid=S1657-07902005000100004

19. Graham S., \& Sandmel K. (2011). The process writing approach: A meta-analysis. The Journal of Educational Research, 104(6), 396-407. https://doi.org/10.1080/00220671.2010.488703

20. Robitaille J., \& Connelly R. (2006). Writer's resources: From paragraph to essay. Cengage Learning.

21. Pratiwi K. D. (2016). Students' difficulties in writing English (A study at the third semester students of English education program at University of Bengkulu Academic Year 2011-2012). Linguists: Journal of Linguistics and Language Teaching, 3(1).

https://ejournal.iainbengkulu.ac.id/index.php/linguists/article/view/106

22. Fatimah N. (2018). Students' needs for academic writing at the English education department. English Education Department of English Language Teaching Educational Journal (ELTEJ), 1(3), 161-175. https://doi.org/10.12928/eltej.v1i3.744

23. Ningsih S. (2016). Guided writing to improve the students' writing ability of junior high school students. Indonesian Journal of EFL and Linguistics, 1(2), 129-140. http://dx.doi.org/10.21462/eflj.v1i2.12

24. Fareed M., Ashraf A., \& Bilal M. (2016). ESL learners' writing skills: Problems, factors and suggestions. Journal of Education and Social Sciences, 4(2), 81-92. 10.20547/jess0421604201

25. Olinghouse N. G., \& Wilson J. (2013). The relationship between vocabulary and writing quality in three genres. Reading and Writing, 26(1), 45-65. https://link.springer.com/article/10.1007/s11145-012-93925

26. Graham S., \& Perin D. (2007). Writing next-effective strategies to improve writing of adolescents in middle and high schools. http://dl.ueb.vnu.edu.vn/handle/1247/9990

27. Arici A. F., \& Kaldirim A. (2015). The effect of the process-based writing approach on writing success and anxiety of pre-service teachers. The Anthropologist, 22(2), 318-327. https://doi.org/10.1080/09720073.2015.11891883

28. Kaldirim A. (2014). The impact of 6+1 Analytic Writing and Evaluation Model on sixth grade middle school students' written expression skills. Unpublished Master's Thesis, Dumlupinar University Institute of Educational Sciences, Kutahya.

29. Kansizoglu H. B., \& Bayrak Comert O. (2017). The Effect of the Process Approach on Students' Writing Success: A Meta-Analysis. Cukurova University Faculty of Education Journal, 46(2). https://dergipark.org.tr/tr/download/article-file/358170

30. Kaya B., \& Ates S. (2016). The Effect of Process-Based Writing Focused on Metacognitive Skills-Oriented to Fourth Grade Students' Narrative Writing Skill. Egitim ve Bilim, 41(187).http://dx.doi.org/10.15390/EB.2016.6752

31. Sever E., \& Memis A. (2013). The effects of process-based writing models on primary school 4th grade students' spelling-punctuation skills and writing dispositions. The Black Sea Journal of Social Sciences 5 (9).

32. Yilmaz M., \& Aklar S. (2015). The effect of planned writing and evaluation model on enhancing 5th grade students' composition writing skills. In Bartın University The Journal of Faculty of Education Special Issue on XIV. International Participation Symposium of Primary School Teacher Education (21-23 May, 2015) (pp. 223-23).

33. Alodwan T. A. A., \& Ibnian S. S. K. (2014). The effect of using the process approach to writing on developing university students' essay writing skills in EFL. Review of Arts and Humanities, 3(2), 139-155. 